\title{
Internal Controls and Performance of Selected Tertiary Institutions in Ekiti State: A Committee of Sponsoring Organisations (COSO) Framework Approach
}

\author{
Gideon Tayo Akinleye ${ }^{1} \&$ Adebola Daniel Kolawole ${ }^{2}$ \\ ${ }^{1}$ Department of Accounting, Ekiti State University, Ado - Ekiti, Ekiti State, Nigeria \\ ${ }^{2}$ Department of Accounting, Afe Babalola University, Ado - Ekiti, Ekiti State, Nigeria \\ Correspondence: Adebola Daniel Kolawole, Department of Accounting, Afe Babalola University, PMB 5454, Afe \\ Babalola Way, Ado - Ekiti, Ekiti State, Nigeria. Tel: 234-0-8038-042-554.
}

Received: October 9, 2019

Accepted: November 16, 2019

Online Published: December 2, 2019

doi:10.5430/ijfr.v11n1p405

URL: https://doi.org/10.5430/ijfr.v11n1p405

\begin{abstract}
This study examined the effect of internal controls on performance of selected tertiary institutions in Ekiti state using a committee of sponsoring organisations (COSO) framework approach. The study employed a survey research design. Primary data were obtained and analysed using multiple regression analysis. Findings from the study showed that the overall influence of COSO components of internal control on performance of selected tertiary institutions in Ekiti state was significantly positive. However, Control activities (CA) $(\mathrm{t}=2.487, \mathrm{p}=0.013<0.05)$, Information \& communication (IFC) $(\mathrm{t}=7.195, \mathrm{p}=0.000<0.05)$ and Monitoring activities $(\mathrm{MA})(\mathrm{t}=4.809, \mathrm{p}=0.000<0.05)$ had significant and positive influence on organisational performance of the selected tertiary institutions while Control environment $(C E)(t=0.569, p=0.570>0.05)$ and Risk assessment $(R A)(t=0.446, p=0.656>0.05)$ had positive but insignificant effect on organisational performance of the selected tertiary institutions. The study concluded that internal control had a positive effect on performance and was statistically significant in explaining performance of selected tertiary institutions in Ekiti state. The study thus recommended that those charged with governance in tertiary institutions should strengthen the highlighted components of internal controls.
\end{abstract}

Keywords: COSO framework, internal controls, performance, tertiary institutions

\section{Introduction}

In the recent past, Nigeria has experienced dwindling oil revenue which has subsequently affected federal allocations made available to state governments. This, in turn, has impacted on the subventions available to government owned tertiary institutions in Nigeria. Tertiary institutions in Ekiti State are not left out, considering the low level of federal allocations that come to the State. This necessitates management of higher institutions of learning to put in place various forms of control to ensure proper use of available resources. A strong system of internal controls is thus paramount to efficiently manage the resources available to these tertiary institutions. Eniola and Akinselure (2016) noted that the survival of an organisation depends on the effective and efficient utilisation of resources at its disposal. Every employee within a higher institution of learning, therefore, has a critical role to play in ensuring a functional internal control system. This is because they are ultimately responsible for the appropriate use and control of the resources entrusted to them. An effective control system provides reasonable, but not absolute assurance for the safeguarding of University assets (Gamage, Lock, \& Fernando, 2014). According to Umar and Dikko (2018), internal control effectiveness of an organisation is the extent to which an organisation's system promotes the achievement of its corporate goals and objectives. This study is prompted by questions on how those charged with governance deploy the resources of tertiary institutions to achieve the institutions' set goals and the extent to which functional internal controls instituted by management influence performance of tertiary institutions. Also, to what extent do tertiary institutions ensure strict compliance with internal control procedures since the preparation of accounts for them is not a primary focus? The importance of internal control cannot be undermined given its vast benefits to organisations. This has been affirmed by various related studies (Adetula, Balogun, Uwajeh \& Owolabi, 2016; Ejoh \& Ejom, 2014; Eniola \& Akinselure, 2016; Kisanyanya, 2018; Umar \& Dikko, 2018). Studies have equally shown that internal controls in most organisations are weak, inadequate and not complied with (Adagye, 2015; Akinyomi, 2010). Amissah (2017) 
noted that the effects of weak internal control system cannot be overemphasized as it distorts the plan of the institutions, paves way to financial indiscipline, fraud, errors, irregularities, and misallocation of resources. This was corroborated by the findings of Norvee (2006). The study noted that a weak internal control system was what led to the failures of big companies in the United States of America. This consequently resulted in the development of a framework such as the Committee of Sponsoring Organisations' (COSO) of the Treadway Commission framework (1992). COSO framework was designed to provide useful guidelines that will help to strengthen the internal controls of organisations. Specifically, Uwadie (2013) noted that the benefits that can be derived from the application of the COSO Internal Control Framework are enormous. This is because its application would provide a solid foundation for determining the degree of assurance provided by controls.

The Integrated Framework for internal control systems developed by the Committee of Sponsoring Organisation of Treadway Commission (COSO) was issued in 1992, now updated in 2013. The COSO framework was designed to help businesses establish, assess and enhance their internal control (Uwadiae, 2013). According to the integrated framework, every sound system of internal control must have five components namely: control environment, risk assessment, control activities, information and communication and monitoring of internal control (COSO, 2013). Pickett (2010) noted that the COSO internal control components interact with each other. Few studies have been carried out on the relationship between COSO internal control and performance (Amissah, 2017; Dubihlela and Nqala (2017), Ejoh \& Ejem, 2014; Muraleetharan, 2011; Njeri, 2014). This study thus examined the effect of internal controls on performance of tertiary institutions using the five internal control components of the Committee of Sponsoring Organisations' (COSO) framework. Findings from the study will provide empirical evidence on the unique contribution of each component of the COSO integrated framework in formulating policies that leads to better performance of tertiary institutions in Ekiti state.

\section{Review of Literature: Conceptual Review}

\subsection{Internal Control System}

Frazer (2012) described internal control as the procedures and policies that ensure adherence to management directives. According to Adagye (2015), internal control is designed and installed by the management of an organisation for the growth and survival of the organisation. Ndungu (2013) asserted that internal control systems are a set of organisational procedures and policies that ensure the processing of transactions in a way to avoid theft, waste, and misuse of an organisation's resources. This is in line with the position of Dubihlela and Nqala (2017). In the study conducted by Salihu (2015), internal control system was described as an indispensable mechanism that plays a vital role in all educational institutions towards providing quality education, good and enabling teaching, learning and research environment. Adagye (2015) further noted that the main objectives of an internal control system are to ensure the reliability of financial reporting, efficiency, and effectiveness of operations and compliance with law and regulations. In the view of Ahmad, Othman, and Jusoff (2009), internal control is considered effective if its outcome is in line with the set objectives while Adagye (2015) identified competence and independence of staff members as a measure of effective internal control.

\subsection{COSO Internal Control Components}

The study reviewed the five internal control components of the Committee of Sponsoring Organisations' (COSO) framework of the Treadway Commission namely; the control environment, the entity's risk assessment process, the information and communication systems, control activities, and the monitoring of controls (COSO, 2013). This is to provide conceptual clarifications for the study variables.

\subsubsection{Control Environment}

Uwadiae (2013) described a control environment as the set of standards, processes, and structures that provide the basis for carrying out internal control across an organisation. The study noted that top management has the responsibility to establish functional internal control including expected standards of conduct. The resulting control environment therefore has a pervasive impact on the overall system of internal control. Gamage et al (2014) noted that the control environment includes the attitudes, awareness, and actions of those charged with governance concerning the entity's internal control and their importance in the entity. Additionally, Mire (2016) emphasized that control environment is the foundation on which an effective system of internal control is built and operated while Umar and Dikko (2018) identified element of control environment to include; communication, enforcement of integrity, and ethical values. Dubihlela and Nqala (2017) emphasized that a control environment forms the basis of any system of internal controls. 


\subsubsection{Risk Assessment}

Risk Assessment can be described as the identification of potential errors and implements procedures, policies, and control to detect those errors and prevent them. Mire (2016) noted that risk assessment plays a vital role in the selection of appropriate activities to undertake. According to Frazer (2012), risk assessment helps an organisation to identify and analyse risks relevant to the achievement of set objectives. COSO (1992) pointed out that every organisation is exposed to some kind of risks from both external and internal sources that must be carefully evaluated. The risks would often require prompt actions in addressing them. This was corroborated by Hayali, Dinc, Sarll, Dizman, and Gundogdu (2012). Uwadiae (2013) noted that a precondition to risk assessment involves the establishment of objectives, linked at different levels of the entity. Risk assessment is a dynamic and iterative process which requires management to specify objectives relating to operations, reporting, and compliance with sufficient clarity.

\subsubsection{Control Activities}

According to Uwadiae (2013), control activities are the actions established through policies and procedures that help ensure that management's directives to mitigate risks towards the achievement of set objectives are carried out. The study pointed out that control activities are performed at all levels of the entity, at various stages within business processes and over the technology environment. Such activities may be preventive or detective in nature and may encompass a range of manual and automated activities such as authorisations and approvals, verifications, reconciliations, and business performance reviews. This was buttressed by Mire (2016). Segregation of duties is typically built into the selection and development of control activities. Management should establish control activities to effectively and efficiently accomplish the organisation's objectives and mission. In the view of Amudo and Inanga (2009), the study considered authorisation, segregation of duties, and verification before making the payments, control over access to resources, reconciliation, review operations and supervision as the control activities in any organisation. Mire (2016) however noted that control activities enable organisations to establish suitable procedures to reduce loss.

\subsubsection{Information and Communication}

Another component of the internal control system is to be able to obtain information both horizontally and vertically and ensure communication among employees. Uwadiae (2013) described communication as the continual, iterative process of providing, sharing, and obtaining necessary information. Internal communication is how information is disseminated throughout the organisation, flowing up, down and across the entity. It enables personnel to receive a clear message from senior management that control responsibilities must be taken seriously. External communication enables inbound communication of relevant external information as well as provides information to external parties in response to requirements and expectations. Umar and Dikko (2018) noted that effective communication should be established to include employees at all levels of the organisation. Information and communication focus on the quality and nature of information needed for effective control. Information systems produce reports of operational, financial, and compliance-related information that make it possible to run and control the business (COSO, 1992). Organisations need information at all levels to assist the management in meeting its objectives which should be communicated from top to bottom.

\subsubsection{Monitoring Activities}

Ongoing evaluations, separate evaluations, or combination of the two are used to ascertain whether each of the five components of internal control is present and functioning (Uwadiae, 2013). According to COSO (1992), ongoing monitoring activities are a means by which organisations evaluate the quality of its internal control processes due to the constant change in application of controls. Gamage et al., (2014) adduced this to new personnel, varying effectiveness of implementing the procedures, time and resource constraints or changes in the circumstances for which the internal control system originally was designed. It is important to monitor internal control to determine whether any modifications are necessary. All employees need to understand the organisation's objectives, mission, and responsibilities and risk tolerance levels for monitoring to be most effective (Umar \& Dikko, 2018). Hayali et al (2012) emphasized on continuous monitoring activities of internal control system as a strategic activity for achieving organisational objectives.

\subsection{Performance}

For an organisation to achieve its objectives, it must be able to perform its operations efficiently and effectively (Umar \& Dikko, 2018). Mire (2016) noted that organisation performance is based upon the idea that an organisation is the voluntary association of productive assets to achieve a set objective. This assertion imply that organisations need to adopt effective business practices towards achieving their set objectives and hence, their organisational performance (Umar \& Dikko, 2018). The performance of organisations is measured based on their abilities to achieve their specific 
organisational objectives. Performance measures, according to Cheng (2008), are systems by which organisations monitor their operations and evaluate whether the organisation is attaining its goals. Performance measure, as indicated by Bhimani, Hongren, Datar and Foster (2008), is central to every management control system. Effective performance measurement is essential in ensuring that an organisation's business strategy is successfully implemented. Specifically, Tangen (2003) posits that performance measures are metrics employed to quantify the effectiveness and efficiency of organisational action. This study adopts management efficiency as the basis for measuring performance in tertiary institutions in Ekiti state. Data on management efficiency were obtained through administered close ended questionnaire using five point Likert scale of measurement.

\subsection{Theoretical Framework: Agency Theory and Contingency Theory (CT)}

The theoretical foundations upon which this study is based are agency theory and contingency theory. These theories are pertinent in explaining firm performance.

Agency theory was propounded by Stephen Ross and Barry Mitrick in 1973. Ross is responsible for the economic theory of agency while Barry is responsible for the institutional theory. Agency theory is a useful framework for designing governance and controls in an organisation. Sharma (1997) noted that the agency theory is based on the assumption of separation of ownership and control with managers being autonomous and are likely to increase their gains at the expense of owners. Self-interest of agents in the agency theory was criticized by Bruce, Buck, and Main (2005) as an extremism assumption arguing that it makes goal congruence unrealistic in principal agent relationship since the theory focuses on principal-agent relationship where the principal defines the work and the agent performs the work. Zimmerman (2011) and Asare (2006) further asserted that agency cost will reduce when management interests are aligned with those of the organisation. In the view of Amissah (2017), El-Mahdy and Park (2013), agency loss usually arises where there is no alignment between agents' actions and the principals' interest. But to reduce potential agency loss, Asare (2006) posited that the principal task of those charged with governance is to design and implement internal controls towards achieving the set goals of an organisation. Arwinge (2013) however argued on the contrary. The contingency theory was propounded by an Austrian psychologist known as Fred Edward Fiedler in 1964. The theory claims that there is no best way to organise a corporation, to lead a company, or to make decisions but that optimal course of action is dependent upon the internal and external situation. Proponents of the theory assert that the theory is based on the assumption that no strategy is considered universally superior and that there is no one best way in which a company could be organised (Donaldson, 2006; Venkatraman, 2004). It then means that two organisations should not necessarily have similar internal control systems unless the organisations are identical. Thus the need for and specifics of internal control systems may vary in organisational contexts. Pock (2007) noted that successfully adapting control systems to suit an organisation's contingency characteristics result in effective internal control systems and better organisational performance. Also, Donaldson (2006) and Jokipii (2006) asserted that a connection exists between the structure of internal control systems and contingency characteristics which define the structure of internal control in line with the contingency theory.

\subsection{Empirical Review}

Kisanyanya (2018) evaluated the effect of internal control systems on financial performance of public institutions of higher learning in Vihiga County, Kenya. Specifically, the study examined the effect of control activities, risk assessment, control environment, information and communication and monitoring on financial performance of institutions of higher learning in Vihiga County, Kenya. Survey research design was employed to elicit information from the sampled respondents. Descriptive and multiple regression analysis were used to analyze data obtained. The study revealed that the institutions had adequate and effective control activities which included regular internal audit reports, adequate segregation of duties in the finance and accounts departments and physical controls to prevent excess allocated funds. Umar and Dikko (2018) investigated the effect of internal control on performance of commercial banks in Nigeria. The study employed a survey method to elicit information from respondents. Respondents were selected using a stratified random sampling. Findings from the study revealed a positive and significant relationship between the four components of internal control namely; control environment, control activities, monitoring and risk assessment; and bank performance while information and communication were found to have insignificant positive relationship with bank performance. This was confirmed by the study conducted by Hermanson, Smith, and Stephens (2012) noting that the internal control component strength is positively related to the Chief Audit Executives (CAE) reporting primarily to the audit committee, public company status, and the average tenure of the internal audit function staff etc. Dubihlela and Nqala (2017) researched on internal controls systems and the risk performance characterizing small and medium manufacturing firms in the cape metropole, South Africa. The study was carried out to determine how internal controls are utilised by manufacturing SMEs to 
mitigate and prevent risks, and how internal controls are implemented by manufacturing SMEs. The study followed a qualitative research paradigm, adopting case-based interpretive approach employed to support the data collection, data analysis and data presentation methods. Adetula et al (2016) assessed the internal control system of Nigerian Tertiary Institutions using four tertiary institutions in southwest, Nigeria. Data was collected through the use of a survey questionnaire. The method of data analysis was descriptive statistics. Findings revealed that many components of the internal control system are properly situated except that the internal audit units of those institutions are not independent. Akosile and Akinselure (2016) examined the effect of internal control on the financial management of selected universities in Nigeria. The methodology of the study was based on the survey research approach. One hundred and fifty (150) copies of questionnaire were distributed to elicit information from randomly selected staff members of universities in the southwestern part of Nigeria. The result of the analysis showed that there was a significant relationship between internal control and prudent management of the resources.

Eniola and Akinselure (2016) examined the effect of internal control on financial performance of some selected firms. The research method was based on survey research approach. Respondents were selected using a non-probability sampling method and data obtained from the questionnaire were analysed using multiple regression statistical tools. Findings from the study showed that internal control has a significant relationship with fraud perpetrated in an organisation. Adagye (2015) assessed the effectiveness of the internal control system in tertiary educational institutions in Nasarawa State, Nigeria adopting Nasarawa State Polytechnic located in Lafia as a case study. The study employed a survey research design. Findings showed that budget and management accounting were never used in the institution's operations. Also, the checking of a subordinate by their superior officers is not regular which renders the internal control structure of the Polytechnic ineffective and weak. Salihu (2015) investigated the effect of internal audit on internal controls' effectiveness in tertiary institutions in Adamawa state. The study found out that the components of an internal control system were not properly put in place by the management of the institutions, especially in the area of authorization and approval, supervision, segregation of duties and personnel controls which is capable of resulting in loss of income for the institution. Ejoh and Ejom (2014) examined the impact of internal control activities on the financial performance of tertiary institutions in Nigeria using Cross River state college of education as a case study. The study revealed that measures of control such as, clear separation of role, was in place but staff members were not adequately trained to implement the institution's internal control system. Mawanda (2008) examined the effect of systems of internal control on financial performance in a higher learning institution in Uganda. The study considered internal controls from the perspective of control environment, control activities and internal audit. The measures of financial performance adopted were liquidity, financial reporting, and accountability. Both qualitative and quantitative research approach was employed by using a combination of correlational-survey and case study designs.

\section{Methodology}

The study employed a survey research design. Primary data was obtained through administered self designed closed ended questionnaire which was validated through face validity. Internal control was operationalized using the five components highlighted in the Committee of Sponsoring Organisation (COSO) framework. Eight (8) out of ten (10) tertiary institutions were purposively selected base on their ownership status i.e. federal owned, state owned and privately owned. The choice of the institutions was to capture the heterogeneous characteristics of the sampled institutions. The study population consisted of five hundred and fifty-three (553) staff members of bursary and the internal audit units of the selected tertiary institutions from which a sample size of four hundred and twenty-five (425) respondents were randomly selected.

The sample size was determined by using the Taro Yamane statistical formula as follows:

$$
n=\frac{N}{1+N(e)^{2}}
$$

Where

$\mathrm{n}$ is the desired sample size, $\mathrm{N}$ is Population of the study, e is precision of sampling error at $5 \%$ significance level

$$
\begin{gathered}
n=\frac{553}{1+553(0.05)^{2}} \\
n=425
\end{gathered}
$$


Staff members of bursary and internal audit units were considered because of their role in the institution's operations as regard budget, cost and revenue.

Table 1. List of selected tertiary institutions in Ekiti state

\begin{tabular}{lllll}
\hline Name of Institution & Bursary Staff & Audit Staff & Total Population & Sample Size \\
\hline Federal University, Oye-Ekiti* & 85 & 25 & 110 & 86 \\
\hline Ekiti State University, Ado-Ekiti** & 122 & 60 & 182 & 125 \\
\hline Afe Babalola University, Ado-Ekiti*** & 15 & 3 & 18 & 17 \\
\hline Federal Polytechnic, Ado-Ekiti* & 105 & 18 & 123 & 94 \\
\hline Ajayi Polytechnic, Ado-Ekiti*** & 3 & - & 3 & 3 \\
\hline College of Education, Ikere-Ekiti** & 75 & 16 & 91 & 74 \\
\hline College of Health Technology, Ijero-Ekiti*** & 14 & 4 & 18 & 17 \\
\hline $\begin{array}{l}\text { Fabotas College of Health Technology, } \\
\text { Ado-Ekiti** }\end{array}$ & 8 & - & 8 & 8 \\
\hline Total & 427 & 126 & 553 & 425 \\
\hline
\end{tabular}

Note: *federal owned institutions, ** state owned institutions, *** privately owned institutions

Source: Field survey, 2019

\subsection{Model Specification}

The study adapted the model developed by Eniola and Akinselure (2016) which presented the functional relationship between the dependent and independent variables as follows:

$$
\mathrm{Y}=\beta_{0}+\beta_{1} \mathrm{X}_{1}+\mu
$$

Where

$\mathrm{Y}=$ the Dependent variable, which was represented by Financial performance, $\mathrm{X}_{1}=$ Independent variables, which was represented by Internal Control, $\beta_{0}$ represents the intercept or constant, $\beta_{1}$ represents the regression parameters/ regression coefficient, and $\mu=$ Error term.

To achieve the study objective, the linear regression model was developed by modifying the model of Eniola and Akinselure (2016) to include the five components of a committee of sponsoring committee (COSO) internal control framework. The linear regression model is presented below:

$$
\begin{gathered}
\mathrm{Y}=\mathrm{f}(\mathrm{X}) \\
\mathrm{Y}=\alpha+\beta_{1} \mathrm{X}_{1}+\mu \\
\mathrm{OGP}=\alpha+\beta_{1} \mathrm{IC}+\mu
\end{gathered}
$$

Where,

OGP $=$ Organisational performance, IC $=$ Internal Control, $\beta_{0}$ represents the intercept, $\beta_{1}$ represents regression coefficient, and $\mu=$ Error term.

In substituting the variables under consideration, the multiple linear regression analysis that depicted the functional relationship between the organisational performance (OGP) and the five components of COSO integrated framework will appear thus:

$$
\mathrm{OGP}=\alpha+\beta_{1} \mathrm{CE}+\beta_{2} \mathrm{RA}+\beta_{3} \mathrm{CA}+\beta_{4} \mathrm{IFC}+\beta_{5} \mathrm{MA}+\mu
$$

Where

$\mathrm{OGP}=$ Organisational performance, $\mathrm{CE}=$ Control Environment, $\mathrm{RA}=$ Risk Assessment, $\mathrm{CA}=$ Control Activities, $\mathrm{IFC}=$ Information and Communication, $\mathrm{MA}=$ Monitoring Activities, $\beta_{0}$ represents the intercept, $\beta_{1}, \beta_{2}, \beta_{3}, \beta_{4}, \beta_{5}$ represent regression coefficient of each of the explanatory variables and $\mu=$ Error term. 


\section{Results and Discussion of Findings}

\subsection{Response Rate}

Table 2. Response rate

\begin{tabular}{lll}
\hline Details & Frequency & Percentage \\
\hline Distribution of Questionnaires & 424 & $100 \%$ \\
\hline Questionnaires filled and returned & 325 & $76 \%$ \\
\hline Questionnaires valid for analysis & 310 & $73 \%$
\end{tabular}

Source: Field survey, 2019

As shown in Table 2, a total number of four hundred and twenty-five (425) questionnaires were distributed to staff members of bursary and internal audit department of selected tertiary institutions in Ekiti state. Three hundred and twenty-five (325) questionnaires were returned representing a 76\% response rate while three hundred and ten (310) questionnaires were valid for analysis which represented a $73 \%$ response rate achieved for this study. The number of questionnaires available for analysis was good.

\subsection{Reliability Test}

The study performed reliability and sampling adequacy tests. The reliability test was based on Cronbach's Alpha test while the sampling adequacy test was based on Keiser-Meyer-Olkin (KMO) measure of sampling adequacy and Bartlett's test of sphericity.

Table 3. Reliability test

\begin{tabular}{lll}
\hline Variables & Cronbach' s Alpha & No of Items \\
\hline Control environment & 0.769 & 5 \\
\hline Risk Assessment & 0.648 & 4 \\
\hline Control Activities & 0.747 & 4 \\
\hline Information \& Communication & 0.663 & 3 \\
\hline Monitoring Activities & 0.616 & 3 \\
\hline
\end{tabular}

Source: Author's computation, 2019

The study considered Cronbach's Alpha coefficient of Correlation of 0.6 as the benchmark for the predictor variables. Table 3 showed that all the predictor variables passed the reliability tests of 0.6 and above.

Table 4. KMO and Bartlett's test

\begin{tabular}{lll}
\hline Explanatory variables & Sampling adequacy & Sig. \\
\hline Control environment & 0.794 & 0.000 \\
\hline Risk assessment & 0.656 & 0.000 \\
\hline Control activities & 0.754 & 0.000 \\
\hline Information \& communication & 0.620 & 0.000 \\
\hline Monitoring activities & 0.584 & 0.000 \\
\hline
\end{tabular}

Source: Author's computation, 2019 
Furthermore, the study considered 0.5 as the benchmark for sampling adequacy using KMO and Bartlett's test. According to Table 4, all the variables passed the sampling adequacy test of 0.5 and above. All the variables were statistically significant $(\mathrm{p}=0.000<0.05)$ indicating the suitability of the predictor variables.

\subsection{Factor Analysis}

This study employed Principal Component Analysis method to determine the most relevant question to be used for regression analysis. The principal component analysis was based on Eigenvalues greater than 1 . The study, therefore, adopts 1 as the cut off value for its factor loading extraction.

Table 5. Factor analysis of predictor variables

\begin{tabular}{|c|c|c|c|c|}
\hline Explanatory variables & Questionnaire Items & Eigen values & $\begin{array}{l}\text { Factor } \\
\text { (Variance) }\end{array}$ & loading \\
\hline \multirow[t]{5}{*}{ Control environment } & Defined employees' duties & 2.616 & $2.616(52.3)$ & \\
\hline & Organisation chart & 0.747 & & \\
\hline & Accounting manual & 0.688 & & \\
\hline & Segregation of duties & 0.501 & & \\
\hline & Staff work schedule & 0.449 & & \\
\hline \multirow[t]{4}{*}{ Risk Assessment } & Operating budget & 1.979 & $1.979(49.5)$ & \\
\hline & Expenditure controls & 0.885 & & \\
\hline & Regular physical audits & 0.652 & & \\
\hline & Annual audit & 0.484 & & \\
\hline \multirow[t]{4}{*}{ Control Activities } & Existence of internal audit unit & 2.278 & $2.278(56.9)$ & \\
\hline & Internal audit unit independence & 0.685 & & \\
\hline & Internal audit reports & 0.563 & & \\
\hline & Review of internal audit reports & 0.474 & & \\
\hline \multirow{3}{*}{$\begin{array}{l}\text { Information } \\
\text { Communication }\end{array}$} & Effective communication & 1.803 & $1.803(60.1)$ & \\
\hline & Proper documentation & 0.719 & & \\
\hline & Written procedures of operations & 0.478 & & \\
\hline \multirow[t]{3}{*}{ Monitoring Activities } & Internal check are in place & 1.731 & $1.731(57.7)$ & \\
\hline & Regular internal checking activities & 0.818 & & \\
\hline & Restricted access & 0.451 & & \\
\hline
\end{tabular}

Source: Field survey, 2019

Table 5 showed the factor analysis carried out on the questionnaire items used to depict each predictor variable. Only the component with Eigenvalues of 1 and above was extracted as the most suitable question for the predictor variable. The extracted variable also showed the amount of variance in the predictor variables accounted for by the component.

Table 6. Principal component analysis of explanatory variables

\begin{tabular}{llll}
\hline Explanatory variables & Questionnaire Items & Eigenvalues & Extraction (SSL) \\
\hline Control environment & Defined employees' duties & 2.616 & $2.616(52.3)$ \\
\hline Risk Assessment & Operating budget & 1.979 & $1.979(49.5)$ \\
\hline Control Activities & Existence of internal audit unit & 2.278 & $2.278(56.9)$ \\
\hline Information \& Communication & Effective communication & 1.803 & $1.803(60.1)$ \\
\hline Monitoring Activities & Internal check is in place & 1.731 & $1.731(57.7)$ \\
\hline
\end{tabular}

Source: Author's computation, 2019 
Table 6 showed the most relevant component extracted from the analysis based on the extraction parameter of Eigenvalue above 1. The components are; Defined employees duties $(\mathrm{EV}=2.616,52.3)$, Operating budget $(\mathrm{EV}=$ $1.979,49.5)$, Existence of internal audit unit $(\mathrm{EV}=2.278,56.9)$, Effective communication $(\mathrm{EV}=1.803,60.1)$, and Internal check is in place $(\mathrm{EV}=1.731,57.7)$. The extracted components were then used to carry out regression analysis.

\subsection{Regression Analysis}

Table 7. Multiple regression analysis

\begin{tabular}{lllllll}
\hline Model & $\mathrm{R}$ & $\mathrm{R}^{2}$ & Adjusted R $^{2}$ & F Change & Sig. F Change & Durbin-Watson \\
\hline 1 & $.638^{\mathrm{a}}$ & .407 & .397 & 41.694 & 0.000 & 1.905
\end{tabular}

Note : a. Predictors: (Constant), Internal check is in place, Operating budget, Existence of internal audit unit, Defined employees' duties, Effective communication

b. Dependent Variable: Management efficiency

Source: Author's computation, 2019

Table 7 presented the summary statistics for the regression analysis showing the effect of internal control on performance of selected tertiary institutions in Ekiti state. From the table, the multiple correlation coefficients $(\mathrm{R}=$ $63.8 \%$ ), represent the linear correlation between the observed and model-predicted values of the dependent variable. Its large value revealed a positive and strong relationship between the predictor variables and the dependent variable. From the table above, $\mathrm{R}^{2}$ is $40.7 \%$, adjusted $\mathrm{R}$ Square is $39.7 \%$ and $F$-statistics is 41.694 with p-value $=0.000<0.05$. The result of Durbin Watson stood at an acceptable level of 1.905. The results from the multiple regression analysis therefore showed that $40.7 \%$ variation in the dependent variable, organisational performance (OGP) is accounted for by the predictor variables, Control environment (CE), Risk assessment (RA), Control activities (CA), Information \& communication (IFC) and Monitoring activities (MA) when taking as a whole. Also, considering the overall influence of all the components of the COSO internal control framework on organisational performance of the selected tertiary institutions, the results showed that COSO internal control components had significant influence on organisational performance of the selected tertiary institutions $(F=41.694, p<0.05)$.

Table 8. Coefficient of predictor variables

\begin{tabular}{lcccc}
\hline & $\mathrm{B}$ & Std. Error & $\mathrm{T}$ & Sig. \\
\hline (Constant) & .234 & .144 & 1.627 & .105 \\
\hline Control environment & .029 & .052 & .569 & .570 \\
\hline Risk assessment & .023 & .052 & .446 & .656 \\
\hline Control activities & .147 & .059 & 2.487 & .013 \\
\hline Monitoring activities & .391 & .054 & 4.195 & .000 \\
\hline
\end{tabular}

Source: Author's computation, 2019

In addition, the study revealed that internal control had positive influence on the performance of selected tertiary institutions in Ekiti state in terms of Control environment (CE), Risk assessment (RA), Control activities (CA), Information \& communication (IFC) and Monitoring activities (MA). However, only 3 out of the 5 predictor variables were statistically significant to explain the unique variance in the dependent variables. Considering the influence of each component of internal control on the organisational performance, the results showed that Control activities $(\mathrm{CA})(\mathrm{t}=2.487, \mathrm{p}=0.013<0.05)$, Information \& communication (IFC) $(\mathrm{t}=7.195, \mathrm{p}=0.000<0.05)$ and Monitoring activities (MA) $(\mathrm{t}=4.809, \mathrm{p}=0.000<0.05)$ had significant and positive influence on organisational performance of the selected tertiary institutions while Control environment $(\mathrm{CE})(\mathrm{t}=0.569, \mathrm{p}=0.570>0.05)$ and 
Risk assessment $(\mathrm{RA})(\mathrm{t}=0.446, \mathrm{p}=0.656>0.05)$ had positive but insignificant effect on organisational performance of the selected tertiary institutions.

Incorporating the coefficient of the predictor variables, the multiple regression analysis can be written as follows:

$$
\mathrm{OGP}=0.234+0.029 \mathrm{CE}+0.023 \mathrm{RA}+0.147 \mathrm{CA}+0.391 \mathrm{IFC}+0.272 \mathrm{MA}+\mu
$$

Equation 6, depicted that organisational performance of selected tertiary institutions in Ekiti state will be enhanced on average by $0.029,0.023,0.147,0.391$, and 0.272 given a 1 unit increase in each of factors that contributes to improved control environment, better risk assessment, increased control activities, improved information dissemination and effective communication and increased monitoring activities respectively.

\subsection{Discussion of Findings}

The study empirically investigated the effect of internal control on performance of selected tertiary institutions in Ekiti state using the five components of the committee of sponsoring organisation (COSO) framework. Internal checks on high risk areas within the selected tertiary institutions were examined. The findings from the study showed that internal control has a positive and unique contribution to explaining the performance of tertiary institutions in Ekiti state $(F=41.694$ with p-value $=0.000<0.05)$. There are, however, other factors that influence the performance of the institutions not captured in the study. Moreover, the study revealed that functional systems of internal control exist in tertiary institutions in Ekiti state and they are developed based on the five internal control components of COSO integrated framework. The selected institutions adhered to the internal controls procedures put in place by management such as segregation of duties, use of staff work schedule, use of operating budget, regular physical audits, internal audit functions, effective communication, proper documentations, and regular internal checking activities. This agreed with the findings of Adetula et al (2016) but did not agree with the study carried out by Adagye (2015). Also, the study found that the all the components of COSO internal controls had a positive association with performance of selected tertiary institutions. This is in line with the findings of Amissah (2017). However, two components of the COSO framework; control environment and risk assessment, were positive but not significant.

\section{Conclusion and Recommendations}

Based on the findings from the study, it can be noted that the selected tertiary institutions' in Ekiti state performed better in their control activities, information and communication, and monitoring activities and that improvement in the components of the COSO internal control framework leads to improved performance. The study thus concluded that internal control had a positive effect on performance and was statistically significant in explaining the performance of selected tertiary institutions in Ekiti state. The study recommended that those charged with governance in tertiary institutions in Ekiti should strengthen the highlighted components of internal controls as it will help to further improve the institutions' performance. Also, management should specifically strengthen its control environment and risk assessment procedures.

This study focused on internal control system and how it contributed to improved performance of tertiary institutions in Ekiti state using components of the COSO framework notwithstanding the ownership status. Further studies can be carried out on the comparative study of the effect of internal control system on performance of the 3-tier tertiary institutions, that is, federal owned institutions, state owned institutions and privately owned institutions, in Nigeria. This would provide empirical evidence on whether the ownership status of tertiary institutions in Nigeria influences how each component of the COSO framework affect their performance. Future research could equally be carried out on internal control system of tertiary institutions in other parts of Nigeria.

\section{References}

Abiola, I., \& Oyewole, A T. (2013). Internal control system on fraud detection: Nigeria Experience. Journal of Accounting and Finance, 13(5), 141-152.

Adagye, I. D. (2015). Effective Internal Control System in the Nasarawa State Tertiary Educational Institutions for Efficiency: A Case of Nasawa State Polytechnic, Lafia. International Journal of Educational and Pedagogical Sciences, 9(11) 3902-3907.

Adetula, D. T., Balogun, S., Uwajeh, P., \& Owolabi, F. (2016). Internal control system in Nigerian Tertiary Institutions. Innovation Management and Education Excellence Vision 2020: Regional Development to Global Economic Growth (pp. 4505-4508).

Ahmad, N. H., Othman, R., \& Jusoff, K. (2009). The Effectiveness of Internal Audit in Malaysian Public Sector. Journal of Modern Accounting and Auditing. 
Akinyomi, O. J. (2010). The effect of internal control system on Nigerian banks. International Journal of Accounting, 2(2), 123-129.

Akosile, A. I., \& Akinselure, O. P. (2016). Effect of Internal Control on Financial Management of Universities in Nigeria: A study of some selected universities in South west, Nigeria. International Journal of Economics, Commerce and Management, 4(7), 552-572.

Amissah, A. (2017). Effect of Internal Control Systems on Performance of Companies in the Insurance Industry in Ghana. Masters of Commerce in Accounting, Department of Accounting and Finance, School of Business, $\begin{array}{lllll}\text { University of Cape } & \text { Coast. } & \text { Retrieved }\end{array}$ https://erl.ucc.edu.gh/jspui/bitstream/123456789/3086/1/anthony\%20amissah.pdf

Amudo, A., \& Inanga, E. L. (2009). Evaluation of Internal Control Systems: A Case Study from Uganda. International Research Journal of Finance and Economics, 1(27), 124-144.

Arwinge, O. (2013). Internal control: A study of concept and themes. Heidelberg, Germany: Physica-Verlag Heidelberg. https://doi.org/10.1007/978-3-7908-2882-5

Asare, T. (2006, May 5). Beating occupational fraud through awareness and prevention. Paper presented at the African Capacity Building Foundation Brown Bag Seminar, Harare, Zimbabwe.

Bhimani, A., Horngren, T. C., Datar, S., \& Foster, G. (2008). Management and cost accounting (4th ed.). Upper Saddle, New Jersey: Pearson Education Limited.

Bruce, A., Buck, T., \& Main, B. G. (2005). Top executive remuneration: A view from Europe. Journal of Management Studies, 42(7), 1493-1506. https://doi.org/10.1111/j.1467-6486.2005.00553.x

Cheng, C. B. (2008). Performance evaluation for a balanced scorecard system by group decision making with fuzzy assessments. International Journal of Applied Science and Engineering, 6(1), 53-69.

COSO. (1992). Internal Control - Integrated Framework (executive summary). Jersey City. Retrieved from www.coso.org/documents/Internal Control-Integrated Framework.pdf

COSO. (2013). COSO - Internal control / integrated framework executive summary. Committee of Sponsoring Organisation of the Treadway Commission (pp. 1-8).

Donaldson, L. (2006). The contingency theory of organizational design: Challenges and opportunities. Information and Organization Design Series, 6, 19-40. https://doi.org/10.1007/0-387-34173-0_2

Ejoh, N., \& Ejom, P. (2014). The impact of internal control activities on financial performance of tertiary institutions in Nigeria. Journal of Economics and Sustainable Development, 5(16), 133-143.

El-Mahdy, F. D., \& Park, S. M. (2013). Internal control quality and information asymmetry in the secondary loan market. Review of Quantitative Finance and Accounting, 43(4), 683-720. https://doi.org/10.1007/s11156-013-0389-1

Eniola, O. J., \& Akinselure, O. P. (2016). Effect of Internal Control on Financial Performance of Firms in Nigeria: A Study of Selected Manufacturing Firms. IOSR Journal of Business and Management, 18(10), 80-85. https://doi.org/10.9790/487X-1810048085

Frazer L. (2012). The Effect of Internal Control On The Operating Activities Of Small Restaurants. Journal of Business \& Economics, 10(6), 361. https://doi.org/10.5539/ijef.v4n3p46

Gamage, C. T., Lock, K. L., \& Fernando, A. A. (2014). A Proposed Research Framework: Effectiveness of Internal Control System in State Commercial Banks in Sri Lanka. International Journal of Scientific Research and Innovative Technology, 1(5), 25-44.

Gyasi, K. (2013). A comprehensive approach to auditing: An invaluable guide for the auditing profession. Accra, Ghana: Kwabotwe Hill Publishers

Hayali, A., Dinç, Y., Sarılı, S., Dizman, A. S., \& Gündoğdu, A. (2012). Importance of internal control system in banking sector: Evidence from Turkey. Doctoral dissertation, Marmara University, Turkey.

Hermanson, D. R., Smith, J. L., \& Stephens, N. M. (2012). How effective are organizations' internal controls? Insights into specific internal control elements. Current Issues in Auditing, 6(1), A31-A50. https://doi.org/10.2308/ciia-50146

Hodges, J., \& Gill, R. (2014). Sustaining change in organizations. Washington, DC: SAGE. 
Jokipii, A. (2006). The structure and effectiveness of internal control: A contingency approach. Doctoral dissertation, University of Vaasa, Finland. Retrieved from http://www.uva.fi/materiaali/ pdf/isbn_952- 476-161-0.pdf

Kisanyanya, G. A. (2018). Internal Control Systems and Financial Performance of Public Institutions of Higher Learning in Vihiga County, Kenya. Doctoral dissertation, Kenyatta University.

Mire, H. A. (2016). Effects of internal control system on the organizational performance of remittance companies in Mogadishu Somalia. IJRDO-Journal of Business Management.

Muraleetharan, P. (2011). Internal control and its impact on financial performance of public and private organizations in Jaffna district. Retrieved from http://www.kln.ac.1k/fcms/icbi2011/paper

Ndungu, H. (2013). The effect of internal controls on revenue generation: A case study of the University of Nairobi Enterprise and Services Limited. Master's dissertation, University of Nairobi, Kenya. Retrieved from http://chss.uonbi.ac.ke/sites/default/files/chss

Njeri, C. K. (2014). Effect of internal controls on the financial performance of manufacturing firms in Kenya. Master's Dissertation, University of Nairobi, Kenya. Retrieved from http://www.chss.uonbi.ac.ke/site/de fault/.../carol\%20kamau\%20final\%20report.pdf

Noorvee, L. (2006). Evaluation of the Effectiveness of Internal Control over Financial Reporting. Unpublished M. Sc. Thesis, University of Tartu.

Pickett, K. H. S. (2010). The internal auditing handbook (3rd ed.). West Sussex, England: Wiley and Sons.

Pock, T. (2007). Contingency-based design of management control systems. Doctoral dissertation, University of St. Gallen, Switzerland. Retrieved from http://www.1.unisg.ch/edis.nsf/SysLkpByIDent

Salihu, A. M. (2015). Impact of internal audit unit on the effectiveness of internal control system of tertiary educational institutions in Adamawa State, Nigeria. International Journal of Humanities Social Sciences and Education, 2(5), 140-156.

Sharma, A. (1997). Professional as agent: Knowledge asymmetry in agency exchange. Academy of Management review, 22(3), 758-798. https://doi.org/10.5465/amr.1997.9708210725

Tangen, S. (2003). An overview of frequently used performance measures. Work Study, 52(7), 347-354.

Umar, H., \& Dikko, M. U. (2018). The effect of internal control on performance of Commercial banks in Nigeria. International Journal of Management Research \& Review, 8(6), 13-32.

Uwadiae, O. (2013). COSO - An Approach to Internal Control Framework. Financial Reporting, Delloite. Retrieved from

https://www2.deloitte.com/content/dam/Deloitte/ng/Documents/audit/Financial\%20Reporting/ng-coso-an-appro ach-to-internal-control-framework.pdf

Venkatraman, N. (2004). The concept of fit in strategy research: Toward verbal and statistical correspondence. Academy of Management Review, 14(1), 423-44. https://doi.org/10.5465/amr.1989.4279078

Zimmerman, J. L. (2011). Accounting for decision making and control (7th ed.). New York, NY: McGraw-Hill. 